News, Notes and Queries

\title{
BRITISH SOCIETY FOR THE HISTORY OF MEDICINE SEVENTH BRITISH CONGRESS ON THE HISTORY OF MEDICINE
}

THE Seventh British Congress on the History of Medicine will be held in Churchill College, Cambridge, from 10-13 September 1969. This will be the third residential congress in the series, and those who attended the sixth congress in the University of Sussex in September 1967 will recall how successful and enjoyable that meeting was.

The subject chosen for the Congress theme is an important one, being 'Cambridge and its Contribution to Medicine'. A distinguished group of speakers, mostly drawn from Cambridge University, will discuss the role of their university and medical school in Anatomy and Physiology, Biochemistry, Nutrition, Genetics, and Clinical Medicine. The whole will provide a completely fresh and unparalleled historical survey of the development of the medical sciences in Cambridge. The final session, on the Saturday morning, will be devoted to the History of Medical Education in Cambridge.

Congress members and their guests have been invited to a reception by the Board of Governors of the United Cambridge Hospitals, of which the Chairman is Lord Todd (Wednesday, 10 September, 6-8 p.m.); and another by the Regius Professor of Physic, Professor J. S. Mitchell, C.B.E., F.R.S. (Thursday, 11 September, 6-8 p.m.).

The entire residential accommodation is provided in Churchill College and the scientific sessions will be held in the Wolfson Hall at the College. As this accommodation is strictly limited early application is recommended.

All correspondence concerning the Congress should be addressed to:

Dr. F. N. L. POYNTER

WeLlCOME INSTITUTE OF THE History OF MEDicine

183 Euston ROAD, LONDON, N.W.1.

\section{MUSEUM OF THE HISTORY OF MEDICINE AT THE UNIVERSITY OF THE WITWATERSRAND-JOHANNESBURG}

This museum, which to date is the first of its kind in the Republic of South Africa, is situated in the grounds of the South African Institute for Medical Research in the very heart of medical activities in the City of Johannesburg in very close proximity to the Johannesburg General Hospital, to the Medical School and various private medical institutions.

The prime object of the Museum is to collect and preserve all material which illustrates the history of medicine and its allied sciences, dentistry, pharmacy, etc., in general and of South Africa in particular. This material will be used for teaching purposes and for research. Lectures, films and exhibitions will continue to be arranged.

The Museum has acquired, since its establishment five years ago, a very large number of medical and surgical instruments and items of equipment of historic interest, several thousand reprints on historical medical subjects, many of which are illustrated. Its reference library grows apace. It has over 300 textbooks devoted 


\section{News, Notes and Queries}

to the history of medicine. It has over 300 rare books as well as more than 300 other useful reference books. In addition there is a fairly comprehensive collection of books on various subjects written by South African doctors, most of which have been autographed by the authors.

The Museum has several thousand pictures, illustrations and photographs, already indexed, as well as a large number of slides depicting the history of medicine. The Museum owns a large collection of medals and medallions of historical medical interest and the nucleus of a stamp collection-medicine in philately.

Public lectures have been delivered here and overseas under the auspices of the Museum of the History of Medicine. A number of exhibitions have been displayed. An exhibition set up by this Museum on the 'Contributions to Medicine by some ancient Italian Universities' was on display in the Clare Ward Gallery, B.M.A. House, London, at the invitation of the British Medical Association.

Another important facet of the activities of the Museum is to collect and to preserve all material associated with the treatment of the sick and injured of the Bantu section of our population as practised by their own herbalists and 'witch doctors' in accordance with their own beliefs and traditions. It is essential that all this material be preserved before it is lost to western influences in medicine.

Invaluable contacts have been established and are being maintained with similar institutions on the Continent of Europe, England and in the United States of America.

The University of the Witwatersrand, its Medical Graduate Association and the South African Institute for Medical Research have already recognized that the Museum is destined to play a most significant part in the cultural and educational activities in the Republic of South Africa.

In addition to the Museum there exists a Students' History of Medicine Society in Johannesburg. These students are the medical students of the Witwatersrand University, one of whom recently won an award for an essay on Osler.

In Cape Town, the 'mother city' of the Republic, there is a flourishing Medical History Club, and a similar one has been established in Bloemfontein.

There are also a handful of medical men who write on historical medical subjects, and their writings are published in the medical press of the country. Their articles are usually on the history of various aspects of medicine, including the medicine of the Bantu inhabitants of the Republic.

Cyril Adler and E. B. Adler

\section{COMMEMORATIVE SYMPOSIUM ON J. E. PURKYNĚ}

ON the occasion of the 100th anniversary of the death of Purkyne, it is intended to organize a symposium about the development of the biological sciences in the nineteenth century, under the chairmanship of Professor V. Kruta, in Prague and Liblice from 8 to 10 September 1969. The symposium will be organized by the Physiological Section of the Czechoslovak Medical Society J. E. Purkyne and the Czechoslovak Society for the History of Science and Technology.

The main themes will be:

Development of physiology and biological sciences in the nineteenth oentury. 